\title{
Organic matter composition and stabilization in a polygonal tundra soil of the Lena Delta
}

\author{
S. Höfle ${ }^{1}$, J. Rethemeyer ${ }^{1}$, C. W. Mueller ${ }^{2}$, and S. John ${ }^{1}$ \\ ${ }^{1}$ Institute of Geology and Mineralogy, University of Cologne, Cologne, Germany \\ ${ }^{2}$ Lehrstuhl für Bodenkunde, Technische Universität München, Freising, Germany \\ Correspondence to: S. Höfle (silke.hoefle@uni-koeln.de) \\ Received: 22 August 2012 - Published in Biogeosciences Discuss.: 12 September 2012 \\ Revised: 21 February 2013 - Accepted: 26 February 2013 - Published: 8 May 2013
}

\begin{abstract}
This study investigated soil organic matter (OM) composition of differently stabilized soil OM fractions in the active layer of a polygonal tundra soil in the Lena Delta, Russia, by applying density and particle size fractionation combined with qualitative $\mathrm{OM}$ analysis using solid state ${ }^{13} \mathrm{C}$ nuclear magnetic resonance spectroscopy, and lipid analysis combined with ${ }^{14} \mathrm{C}$ analysis. Bulk soil OM was mainly composed of plant-derived, little-decomposed material with surprisingly high and strongly increasing apparent ${ }^{14} \mathrm{C}$ ages with active layer depth suggesting slow microbial OM transformation in cold climate. Most soil organic carbon was stored in clay and fine-silt fractions $(<6.3 \mu \mathrm{m})$, which were composed of little-decomposed plant material, indicated by the dominance of long $n$-alkane and $n$-fatty acid compounds and low alkyl/O-alkyl C ratios. Organo-mineral associations, which are suggested to be a key mechanism of OM stabilization in temperate soils, seem to be less important in the active layer as the mainly plant-derived clay- and fine-silt-sized OM was surprisingly "young", with ${ }^{14} \mathrm{C}$ contents similar to the bulk soil values. Furthermore, these fractions contained less organic carbon compared to density fractionated OM occluded in soil aggregates - a further important OM stabilization mechanism in temperate soils restricting accessibility of microorganisms. This process seems to be important at greater active layer depth where particulate OM, occluded in soil aggregates, was "older" than free particulate OM.
\end{abstract}

\section{Introduction}

The Lena Delta-Laptev Sea region is a key area for studies on the Arctic carbon cycle. The area hosts one of the largest Arctic rivers, the Lena River, with a length of $4337 \mathrm{~km}$, (Lobbes et al., 2000) and its drainage basin is located almost entirely within the zone of permanent permafrost. About $18 \%$ of the total dissolved organic carbon (DOC) and $12-14 \%$ of particulate organic carbon (POC) discharged into the Arctic Ocean are transported by the Lena River (Dittmar and Kattner, 2003) with the major component being terrestrial organic matter (OM) (Lara et al., 1998; Fahl and Stein, 2007).

Previous studies suggest that much of the terrestrial OM in the Lena River and Laptev Sea shelf derives from permafrost soils and riverbank erosion (Charkin et al., 2011; Gustafsson et al., 2011), including an increasing portion of old, strongly transformed DOC and POC most probably exported from thawing permafrost soils (Guo et al., 2007; van Dongen et al., 2008; Gustafsson et al., 2011). However, most of these studies are identifying terrestrial OM from analyses of river and marine sediments as well as of suspended material from both systems (e.g. Schubert and Stein, 1997; Dittmar and Kattner, 2003; Karlsson et al., 2011; Semiletov et al., 2011), but detailed information on the original source, plant material and soil OM in the hinterland of the Laptev Sea area are missing. Few investigations have been conducted so far of the active layer in permafrost soils, which thaws during summer, as a potential source of terrestrial OM to Arctic rivers and the ocean. Due to the expected increase in active layer thickness, which was already proven in some studies (Hinkel and Nelson, 2003; Nelson et al., 2008; Akerman and Johansson, 2008), and which is predicted to accelerate due to global warming (Anisimov and Reneva, 2006; Schaefer et al., 2011), previously frozen OM will become increasingly available for microbial decomposition and export by water (Zimov et al., 2006; Frey and McClelland, 2009). A recent study on polygonal tundra soils in the Lena Delta showed the 
importance of the active layer for soil organic carbon storage with on average $7.6 \mathrm{~kg} \mathrm{~m}^{-2}$ organic carbon in the active layer (Zubrzycki et al., 2012). However, so far little is known about OM distribution and composition in the active layer and therefore the susceptibility of different OM components to degradation and export into rivers and the Arctic Ocean. Although still discussed controversially, several results from incubation experiments of Arctic soils indicate that microbial activity is temperature sensitive (Guicharnaud et al., 2010) and that after decomposition of labile OM, recalcitrant components will be decomposed at higher soil temperatures due to microbial community changes (Biasi et al., 2005; Knoblauch et al., 2008). However, OM bound to soil minerals may survive biodegradation as suggested by Vonk et al. (2010), who measured high ${ }^{14} \mathrm{C}$ ages of vascular plantderived lipids in sediments in front of Arctic river mouths (Vonk, 2010; Gustafsson et al., 2011). Physical and chemical stabilization processes, which are considered to play an important role for OM stabilization in soils and sediments (Arnarson and Keil, 2007; Kögel-Knabner et al., 2008; Marschner et al., 2008), have not been investigated in the active layer of permafrost soils.

OM stabilization has been investigated quite intensively in temperate surface soils (Sollins et al., 1996; von Lützow et al., 2007; Kögel-Knabner et al., 2008). There, physical protection mechanisms were found to be more important for soil OM stabilisation than (intrinsic) chemical recalcitrance of organic compounds (Marschner et al., 2008). However, the active layer soils of permafrost regions differ strongly from temperate soils, e.g. it often contains less mineral substrate, has high root penetration, and is affected by freezing and thawing processes, which may influence aggregation processes.

Various fractionation methods have been used to separate differently stabilized OM and thereby gain information on stabilization processes (von Lützow et al., 2007), which produce quite heterogeneous $\mathrm{OM}$ fractions not representative for distinct functional pools (von Lützow et al., 2007; Trumbore, 2009). Therefore, a combination of ${ }^{14} \mathrm{C}$ and qualitative analysis of soil physical fractions was proposed, which identifies carbon turnover and the chemical properties of OM on a molecular level (Quideau et al., 2000; Schöning and KögelKnabner, 2006; Trumbore, 2009). This integrative approach has been applied in marine and terrestrial environments giving useful insights into carbon sources and dynamics. For example, terrestrial carbon input and turnover has been studied in marine sediments of rivers continental margins (Dickens et al., 2006; Wakeham et al., 2009), while in soils different OM sources, their stabilization and decomposition have been identified (Baldock et al., 1992; von Lützow et al., 2008; Mueller et al., 2009).

Solid-state ${ }^{13} \mathrm{C}$ nuclear magnetic resonance spectroscopy (NMR), recording the relative abundance of different functional groups, can be used to get a non-destructive overview of the chemical OM composition and its decomposition stage
(Baldock et al., 1992). However, the precise structure of soil $\mathrm{OM}$ or specific organic compounds cannot be determined by this method (Kögel-Knabner, 2000). More detailed information is obtained from macromolecular compounds and diagnostic lipids in soil OM (Simpson and Simpson, 2012). The dynamics of organic carbon in physically defined OM fractions are revealed by ${ }^{14} \mathrm{C}$ analysis.

In this study we investigated the composition of differently stabilized soil OM compartments in the shallow active layer (ca. $25 \mathrm{~cm}$ ) and the uppermost still-frozen permafrost in a polygonal rim on Samoylov Island (Lena Delta, Siberia). Soil OM from different depth intervals was separated by particle size and density fractionation. The composition of ${ }^{14} \mathrm{C}$ dated $\mathrm{OM}$ in silt and clay fractions as well as in free and occluded particulate $\mathrm{OM}$ was characterized by ${ }^{13} \mathrm{C}$ crosspolarization magic angle spinning nuclear magnetic resonance spectroscopy analysis $\left({ }^{13} \mathrm{C}-\mathrm{CPMAS} \mathrm{NMR}\right)$ and lipid analysis.

\section{Material and methods}

\subsection{Site description and sampling}

Polygonal tundra covers a global area of $250000 \mathrm{~km}^{2}$, which is about $3 \%$ of the Arctic land mass (Minke et al., 2007). The polygonal tundra investigated in this study is located on Samoylov Island $\left(72.37^{\circ} \mathrm{N}, 126.48^{\circ} \mathrm{E}\right)$, which is part of the active eastern section of the Lena Delta, Siberia. The Lena Delta is the largest $\left(32000 \mathrm{~km}^{2}\right)$ of the Arctic (Are and Reimnitz, 2000) and is located in the zone of continuous permafrost, which has a thickness of $400-600 \mathrm{~m}$ in the delta (Romanovskii and Hubberten, 2001). The climate is Arctic continental with low mean annual air temperatures of $-14.7^{\circ} \mathrm{C}$, great temperature differences between winter (September-May: $-30^{\circ} \mathrm{C}$ ) and summer (June-August: $7^{\circ} \mathrm{C}$ ), and low mean annual precipitation of $190 \mathrm{~mm} \mathrm{yr}^{-1}$. The island is composed mainly of middle Holocene fluvial deposits (Hubberten et al., 2006). Polygonal patterns, dominating the landscape, have formed due to freezing-thawing cycles of ice wedges (Mueller, 1997). The polygon rims cover about $55 \%$ of the area and the several centimetres lower polygon centres ca. $45 \%$ (Kutzbach et al., 2004). The permafrost affected alluvial soils on Samoylov Island are Gelisols (according to US Soil Taxonomy; FAO, 2007) with suborders Glacic Aquiturbels dominant in the polygon rims and Typic Historthels in the polygon centers (Pfeiffer et al., 2002). Gelisols cover an area of about $27 \%$ in northern latitudes (Jones et al., 2010). Soil texture of the Glacic Aquiturbels is silty sand (Ajj), loamy sand (Bjj) and sandy, loamy silt (Bjj2, Bjjf).

Vegetation is mainly formed by mosses and grasses, and additionally on the polygon rims by lichens, some herbs and small shrubs like Salix spp. or Betula spp. and in the polygon centres by some sedges (Mueller, 1997; Boike et al., 2012). 
Soil sampling was done during the LENA-2009 and LENA-2010 expeditions of the Alfred Wegener Institute, Bremerhaven (Germany; Boike et al., 2009). Samples were taken from a soil pit of about $1 \mathrm{~m} \times 1 \mathrm{~m}$ size from different soil layers of the active layer $(0-25 \mathrm{~cm})$ and of the uppermost still-frozen permafrost $\left(25-30_{\mathrm{p}} \mathrm{cm}\right)$ of a polygon rim (Table 1) with little visible cryoturbation at the end of the summer season in mid-August to the beginning of September, when the active layer has reached its maximal depth. Because of the complex analyses performed, only one soil profile with four soil horizons has been sampled and no replicates were analysed. However, large amounts of soil per horizon were sampled and mixed to obtain a representative sample at least for the soil pits (ca. $1 \mathrm{~m} \times 1 \mathrm{~m}$ ). Thus, spatial heterogeneity of organic matter in the active layer soils (e.g. Jones et al., 2010) is not represented by this sample set.

Sample material was stored and transported frozen in precombusted glass jars at $-20^{\circ} \mathrm{C}$ and freeze-dried prior to analysis.

\subsection{Physical fractionation}

A combined density and particle size fractionation was applied (Mueller et al., 2009). Briefly, $20 \mathrm{~g}$ of soil material were suspended in sodium polytungstate solution $\left(1.8 \mathrm{~g} \mathrm{~cm}^{-3}\right)$ and allowed to settle over night. The floating free particulate organic matter (fPOM) was extracted by sucking via a water jet pump. Sodium polytungstate was removed from the fPOM fraction by washing several times with deionized water on a sieve of $20 \mu \mathrm{m}$ mesh size. The remaining slurry was dispersed ultrasonically (200 $\mathrm{J} \mathrm{mL}^{-1}$; Bandelin, Sonopuls HD 2200) in order to break down soil aggregates. The energy input had been tested before to avoid disruption of coarse POM. After sonication the occluded POM (OPOM) was separated from the mineral residue by centrifugation. The fraction $<20 \mu \mathrm{m}$ $\left(\mathrm{oPOM}_{<20}\right)$ was obtained by washing the oPOM $>20$ over a sieve of $20 \mu \mathrm{m}$ mesh size via pressure filtration until the electric conductivity dropped below $5 \mu \mathrm{S} \mathrm{cm}^{-1}$. Sand (63$2000 \mu \mathrm{m})$ and coarse silt $(20-63 \mu \mathrm{m})$ were separated by wet sieving and medium silt $(6.3-20 \mu \mathrm{m})$, fine silt $(2-6.3 \mu \mathrm{m})$ and clay $(<2 \mu \mathrm{m})$ by sedimentation. All fractions were freezedried and weighed before further analysis. Mass recovery of the SOM fractionation was between $97 \%$ and $99 \%$.

\subsection{Bulk analysis}

Bulk soil samples and soil fractions were manually ground in a porcelain bowl with liquid nitrogen to gain a fine homogeneous material. Total $\mathrm{C}$ and $\mathrm{N}$ contents were determined with an elemental analyser (Analyzer vario MICRO cube, Elementar, Germany). The samples were carbonate-free, therefore total $\mathrm{C}$ contents were set equal to total organic carbon content (TOC). Soil $\mathrm{pH}$ values were measured in $\mathrm{H}_{2} \mathrm{O}$ (soil water ratio $1: 2.5$ ) one hour after water addition.

\subsection{NMR analysis}

For ${ }^{13} \mathrm{C}$ cross-polarization magic angle spinning nuclear magnetic resonance spectroscopy analysis $\left({ }^{13} \mathrm{C}\right.$-CPMAS NMR) accomplished with a Bruker DSX 200 spectrometer (Bruker BioSpin GmbH, Karlsruhe, Germany), samples were filled into zirconium dioxide rotors and spun in a magic angle spinning probe at a rotation speed of $6.8 \mathrm{kHz}$ to minimize chemical anisotropy. A ramped ${ }^{1} \mathrm{H}$ pulse was used during a contact time of $1 \mathrm{~ms}$ to prevent Hartmann-Hahn mismatches. The delay times ranged from $400 \mathrm{~ms}$ for mineral fractions to $1000 \mathrm{~ms}$ for POM fractions. Chemical shifts were referenced to tetramethylsilane $(\mathrm{TMS}=0 \mathrm{ppm})$. For integration, chemical shift regions were used as given: alkyl C (10-45 ppm), O-alkyl C (45-110 ppm), aryl/olefine C (110-160 ppm), and carbonyl/carboxyl/amide C (160-220 ppm). Measurements were done on clay and $\mathrm{oPOM}_{<20}$ fractions for all soil horizons, except for the second horizon $(6-11 \mathrm{~cm})$, where only the clay fraction was measured due to the lack of oPOM $<20$ material.

\subsection{Extraction of lipids}

Lipids were extracted from bulk soil samples by accelerated solvent extraction (Dionex ASE 200, USA) and from soil fractions by sonication. Five (5) g of bulk soil material was extracted by ASE with dichloromethane:methanol $\left(9: 1,75 \mathrm{bar}, 120^{\circ} \mathrm{C}, 20 \mathrm{~min}\right)$. Depending on TOC content, $100-3000 \mathrm{mg}$ of each soil fraction was extracted in an ultrasonic bath (room temperature) with a sequence of solvents starting with methanol, dichloromethane: methanol $(1: 1)$, and finally dichloromethane $(25 \mathrm{~mL}, 5 \mathrm{~min}$ each solvent). The three extracts were combined and solvents were rotary evaporated. After saponification of the total lipid extracts with methanolic $\mathrm{KOH}(0.5 \mathrm{M})$, neutral lipids were recovered by liquid-liquid phase separation and $n$-fatty acids after acidification with $10 \% \mathrm{HCl}$. The neutral fraction was further separated into aliphatic, aromatic and heterocompound fractions by column chromatography using deactivated $\mathrm{SiO}_{2}$ (mesh size 60) and elution with hexane, followed by dichloromethane : hexane $(2: 1)$ and methanol, respectively. The $n$-fatty acid fraction was transesterified with methanolic $\mathrm{HCl}(95: 5)$ to form fatty acid methyl esters (FAMEs) and purified over a $\mathrm{SiO}_{2}-\mathrm{Na}_{2} \mathrm{SO}_{4}$ column by eluting with dichloromethane : hexane $(2: 1)$.

The $n$-alkanes and $n$-fatty acid distributions were measured on a gas chromatography - flame ionization detector (GC-FID, 5890 series II plus, Hewlett Packard, USA equipped with DB-5MS column $50 \mathrm{~m}, 0.2 \mathrm{~mm}$ ID, $0.33 \mu \mathrm{m} \mathrm{df}$ ). Identification and quantification of lipids was done using external standard mixtures. 
Table 1. Bulk soil properties in different depths intervals of a polygonal rim (Glacic Aquiturbels, FAO, 2007) on Samoylov Island, Siberia. Total extractable $n$-alkanes $\left(\mathrm{C}_{19}-\mathrm{C}_{33}\right)$ and $n$-fatty acids $\left(\mathrm{C}_{14}-\mathrm{C}_{30}\right)$ and summed long-chain, mainly plant-wax-derived $n$-alkanes $\left(\mathrm{C}_{27}, \mathrm{C}_{29}\right.$, $\left.\mathrm{C}_{31}\right)$ and $n$-fatty acids $\left(\mathrm{C}_{24}, \mathrm{C}_{26}, \mathrm{C}_{28}\right)$ are related to soil dry weight (DW).

\begin{tabular}{clcccccccc}
\hline $\begin{array}{c}\text { Depth } \\
{[\mathrm{cm}]}\end{array}$ & Horizon & $\mathrm{pH}$ & $\begin{array}{c}\text { TOC } \\
{[\%]}\end{array}$ & $\mathrm{C} / \mathrm{N}$ & $\begin{array}{c}{ }^{14} \mathrm{C} \\
{[\mathrm{pMC}]}\end{array}$ & \multicolumn{2}{c}{$\begin{array}{c}n \text {-alkanes } \\
{\left[\mu \mathrm{g} \mathrm{g}^{-1} \mathrm{DW}\right]}\end{array}$} & \multicolumn{2}{c}{$\begin{array}{c}n \text {-fatty acids } \\
{\left[\mu \mathrm{g} \mathrm{g}^{-1} \mathrm{DW}\right]}\end{array}$} \\
\hline $0-6$ & Ajj & 6.1 & 3.0 & 19.5 & 90 & 17 & 11 & 90 & 24 \\
$6-11$ & Bjjg1 & 6.4 & 1.5 & 17.8 & 83 & 14 & 9 & 52 & 15 \\
$11-25$ & Bjjg2 & 6.3 & 3.0 & 18.4 & 78 & 20 & 11 & 255 & 120 \\
$25-30 \mathrm{p}$ & Bjjf & 6.7 & 2.5 & 16.4 & 68 & 12 & 6 & 178 & 82 \\
\hline
\end{tabular}

\subsection{Radiocarbon analysis}

Bulk soil samples and soil fractions were pretreated with $1 \%$ $\mathrm{HCl}$, which was removed by washing with Milli-Q water. After drying $\left(60^{\circ} \mathrm{C}\right)$ the samples were converted to graphite with $\mathrm{H}_{2}$ over iron as catalyst (Rethemeyer et al., 2013). ${ }^{14} \mathrm{C}$ contents of soil fraction were measured on a $6 \mathrm{MV}$ Tandetron AMS (HVE, the Netherlands) at the University of Cologne (Germany). Bulk soil samples were measured with the MICADAS AMS at the ETH Zurich (Switzerland). ${ }^{14} \mathrm{C}$ results are reported as percent modern carbon (pMC, related to 1950) with one-sigma uncertainties.

\section{Results}

\subsection{Bulk parameters}

\subsubsection{Bulk soil characteristics}

Basic soil parameters of the three depth intervals of the shallow active layer $(25 \mathrm{~cm})$ and the uppermost ca. $5 \mathrm{~cm}$ stillfrozen soil are presented in Table 1. The active layer consists of an upper $6 \mathrm{~cm}$ mineral soil layer with high root penetration and a $19 \mathrm{~cm}$ thick mineral soil with little root penetration. Soil type changed from loamy and silty sand with depth to loamy and sandy silt. Soil OM in the lower mineral soil contained high amounts of only slightly decomposed roots from grasses and small shrubs. The soil layer at $6-11 \mathrm{~cm}$ depth contained sandy material of aeolian or fluvial origin. The $\mathrm{pH}$ values in the active layer and in the uppermost permafrost layer were around 6.5. The four depth intervals yielded relatively high and little variable TOC contents (2.5-3.0\%) except for the $6-11 \mathrm{~cm}$ interval containing a sandy layer, which had a lower content (1.5\%). Similarly, $\mathrm{C} / \mathrm{N}$ ratios were at a comparable level in all soils and centred around 18. Bulk soil $\mathrm{OM}{ }^{14} \mathrm{C}$ concentrations decreased strongly in the shallow active layer from 90 to $68 \mathrm{pMC}$, which is equivalent to an apparent age increase from 866 to $3052 \mathrm{yr}$ BP.

\subsubsection{Basic parameters of soil fractions}

The upper two depth intervals of the active layer $(0-11 \mathrm{~cm})$ and the lowermost intervals $\left(11-30_{\mathrm{p}} \mathrm{cm}\right)$ showed a similar particle size distribution. In the upper two depth intervals, the sand fraction $(63-2000 \mu \mathrm{m})$ was the largest fraction with over $62 \%$ of the total soil mass, but decreased successively with depth down to ca. $25 \%$ at $25-30_{\mathrm{p}} \mathrm{cm}$ depth (Table 2). Clay-sized material showed a strong increase of $10 \%$ with depth. TOC values were very low for both sand fractions (63$2000 \mu \mathrm{m}: 0.1 \%)$ and coarse silt $(20-63 \mu \mathrm{m}:<0.6 \%)$ from all depth intervals. The medium-silt fraction $(6.3-20 \mu \mathrm{m}) \mathrm{had}$ still low and decreasing TOC values with soil depth (0.6$2.0 \%)$. Most organic carbon was located in fine silt (2$6.3 \mu \mathrm{m})$ and clay $(<2 \mu \mathrm{m})$ where TOC values were lower only in these fractions from the still-frozen soil at $25-30_{p}$ $\mathrm{cm}$ depth. TOC storage in the different size fraction related to the mass of each fraction is shown in Fig. 1a, revealing that the fine-silt and clay fractions contained most organic carbon (7.4-15.3 $\mathrm{mg} \mathrm{C} \mathrm{g}^{-1}$ soil dry weight $\left.-\mathrm{DW}\right)$. $\mathrm{C} / \mathrm{N}$ ratios of the silt and clay fractions (20 and 15, respectively) were highest in the surface layer and decreased with particle size as well as with depth to minimal values around 10 in the frozen soil layer.

The three POM fractions made up together between 0.9$2.4 \%$ of the total soil mass (Table 2) and stored together 2.6-7.8 $\mathrm{mg} \mathrm{C} \mathrm{g}^{-1}$ DW (Fig. 2a). While the mass of fPOM strongly decreased with depth by about $40 \%$, the oPOM $>20$ mass distribution was nearly constant except for the sandy 6 $11 \mathrm{~cm}$ depth interval. The mass percentage of the $\mathrm{oPOM}_{<20}$ increased and was twice as high in the lowermost depth interval compared to the surface layer (Table 2). Despite the small masses of the POM fractions they had the highest TOC values $(21-42 \%)$ in all depths intervals. TOC values were constant over depth for fPOM, but increased for oPOM $>20$ and $\mathrm{oPOM}_{<20}$. However, taking the mass of each fraction into account, values for fPOM decreased from $4.7 \mathrm{mg} \mathrm{C} \mathrm{g}^{-1} \mathrm{DW}$ with depth down to $1.8 \mathrm{mg} \mathrm{Cg}^{-1} \mathrm{DW}$, whereas oPOM $>20$ had almost constant values, except in the sandy depth interval (Fig. 2a). In contrast the amount of TOC in $\mathrm{OPOM}_{<20}$ increased with depth. The highest $\mathrm{C} / \mathrm{N}$ ratios of 31 and 34 were measured in the $\mathrm{PPOM}$ and $\mathrm{oPOM} \mathrm{P}_{20}$ fraction in the surface 
Table 2. Fraction mass and elemental composition of density and particle size soil fractions.

\begin{tabular}{|c|c|c|c|c|c|c|c|c|c|c|}
\hline Parameter & $\begin{array}{l}\text { Depth } \\
{[\mathrm{cm}]}\end{array}$ & fPOM & $\mathrm{oPOM}_{>20}$ & $\mathrm{oPOM}_{<20}$ & $\begin{array}{c}\text { Coarse }+ \text { medium } \\
\text { sand } \\
(200-2000 \mu \mathrm{m})\end{array}$ & $\begin{array}{l}\text { Fine sand } \\
(63-200 \mu \mathrm{m})\end{array}$ & $\begin{array}{l}\text { Coarse silt } \\
(20-63 \mu \mathrm{m})\end{array}$ & $\begin{array}{l}\text { Medium silt } \\
(6.3-20 \mu \mathrm{m})\end{array}$ & $\begin{array}{l}\text { Fine silt } \\
(2-6.3 \mu \mathrm{m})\end{array}$ & $\begin{array}{l}\text { Clay } \\
(<2 \mu \mathrm{m})\end{array}$ \\
\hline \multirow[t]{4}{*}{$\operatorname{mass}[\%]$} & $0-6$ & 1.3 & 0.5 & 0.6 & 30.2 & 32.4 & 16.6 & 9.6 & 3.3 & 5.6 \\
\hline & $6-11$ & 0.4 & 0.1 & 0.3 & 31.5 & 36.2 & 14.9 & 8.3 & 3.1 & 5.2 \\
\hline & $11-25$ & 0.7 & 0.4 & 0.7 & 8.4 & 24.3 & 27.6 & 17.1 & 7.8 & 12.9 \\
\hline & $25-30_{\mathrm{p}}$ & 0.5 & 0.5 & 1.2 & 5.5 & 19.7 & 25.8 & 22.3 & 9.4 & 15.0 \\
\hline \multirow[t]{4}{*}{ TOC* $[\%]$} & $0-6$ & 36.9 & 32.9 & 21.2 & 0.1 & 0.1 & 0.6 & 2.0 & 10.9 & 9.8 \\
\hline & $6-11$ & 38.2 & 37.6 & 12.5 & 0.0 & 0.1 & 0.3 & 1.5 & 8.6 & 9.2 \\
\hline & $11-25$ & 37.5 & 40.2 & 31.9 & 0.0 & 0.1 & 0.3 & 1.0 & 8.0 & 7.0 \\
\hline & $25-30 p$ & 37.1 & 42.4 & 32.1 & 0.0 & 0.1 & 0.2 & 0.6 & 5.0 & 5.0 \\
\hline \multirow[t]{4}{*}{$\mathrm{C} / \mathrm{N}$} & $0-6$ & 31 & 34 & 15 & n.d. & n.d. & 30 & 18 & 20 & 15 \\
\hline & $6-11$ & 25 & 28 & 21 & n.d. & n.d. & 25 & 17 & 17 & 13 \\
\hline & $11-25$ & 24 & 29 & 21 & n.d. & n.d. & 14 & 14 & 16 & 12 \\
\hline & $25-30 \mathrm{p}$ & 24 & 24 & 21 & n.d. & n.d. & 9 & 11 & 13 & 11 \\
\hline$n$-alkanes & $0-6$ & 29 & 23 & 69 & n.d. & n.d. & 6 & 17 & 39 & 21 \\
\hline total & $6-11$ & 53 & 68 & 91 & n.d. & n.d. & 8 & 5 & 40 & 44 \\
\hline$\left(\mathrm{C}_{19}-\mathrm{C}_{33}\right)$ & $11-25$ & 15 & 33 & 98 & n.d. & n.d. & 3 & 9 & 35 & 40 \\
\hline$\left[\mu \mathrm{g} \mathrm{g}^{-1} \mathrm{DW}\right]$ & $25-30 p$ & 34 & 20 & 57 & n.d. & n.d. & 2 & 4 & 14 & 16 \\
\hline$n$-fatty & $0-6$ & 394 & 99 & 130 & n.d. & n.d. & 5 & 10 & 80 & 70 \\
\hline acids total & $6-11$ & 1120 & 283 & 390 & n.d. & n.d. & 2 & 3 & 58 & 40 \\
\hline$\left(\mathrm{C}_{14}-\mathrm{C}_{30}\right)$ & $11-25$ & 88 & 386 & 218 & n.d. & n.d. & 2 & 6 & 56 & 57 \\
\hline$\left[\mu \mathrm{gg}^{-1} \mathrm{DW}\right]$ & $25-30 \mathrm{p}$ & 279 & 620 & 223 & n.d. & n.d. & 3 & 8 & 105 & 158 \\
\hline
\end{tabular}

* Total organic carbon.

A)

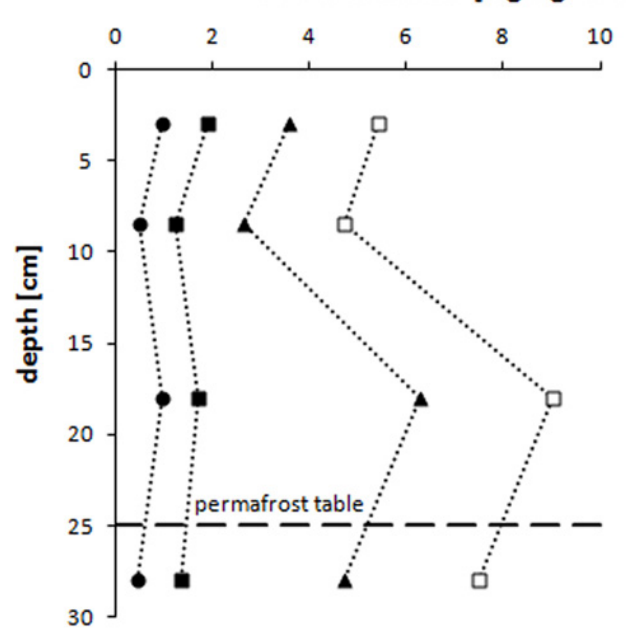

B)

${ }^{14} \mathrm{C}$ content [pMC]

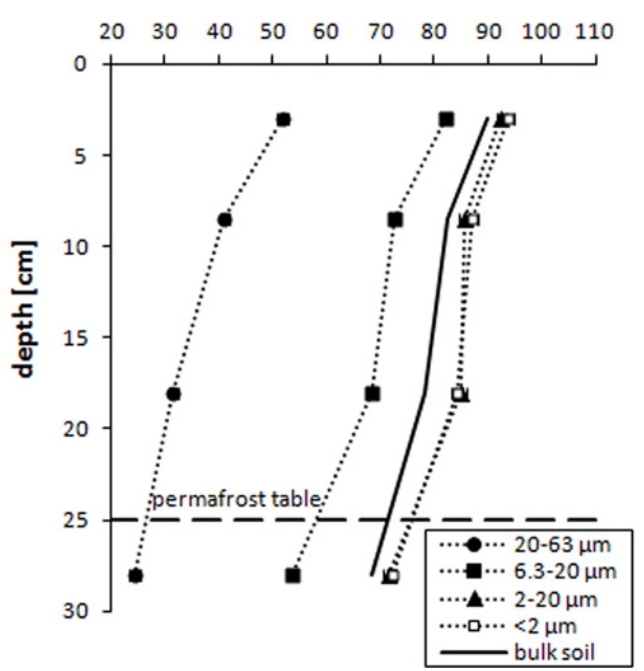

Fig. 1. Distribution of (A) total organic carbon content (TOC) in particle size fractions related to fraction mass and (B) ${ }^{14} \mathrm{C}$ content (onesigma measurement uncertainties are indicated by bars on each point) over depth in the coarse silt $(20-63 \mu \mathrm{m})$, medium silt $(6.3-20 \mu \mathrm{m})$, fine silt $(2-6.3 \mu \mathrm{m})$ and clay $(<2 \mu \mathrm{m})$ fractions.

soil. The $\mathrm{C} / \mathrm{N}$ ratios decreased slightly with depth for these two fractions, whereas the oPOM $<20$ fraction had a lower $\mathrm{C} / \mathrm{N}$ ratio in the uppermost soil (15), which increased in the three subsoil layers to 21 . Generally, decreases in $\mathrm{C} / \mathrm{N}$ ratio with depths were smaller for the POM fractions than for the particle size fractions.

\subsection{NMR results and lipid concentration}

\subsubsection{Lipid concentration of bulk soil}

The $n$-alkane concentrations of the bulk soil showed a clear odd-over-even predominance with the main compounds being $\mathrm{C}_{27}$ and $\mathrm{C}_{29}$ (Table 1). Overall, concentrations $\left(\mathrm{C}_{19}-\mathrm{C}_{33}\right)$ 
A)

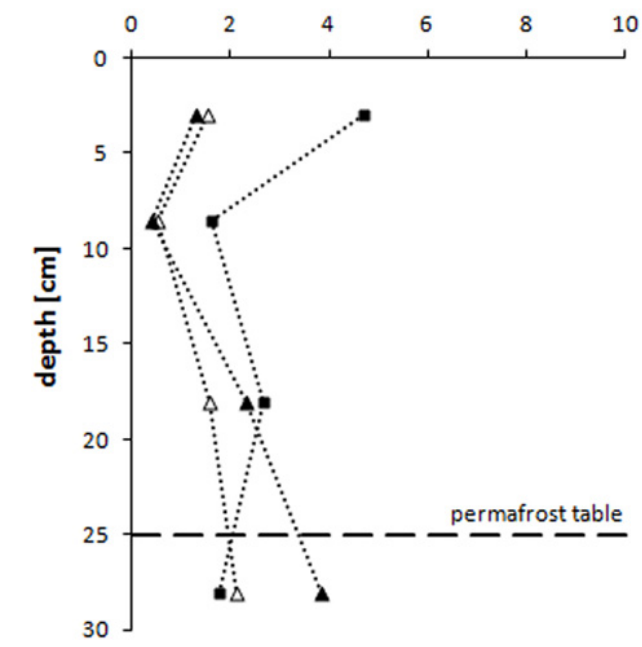

B)

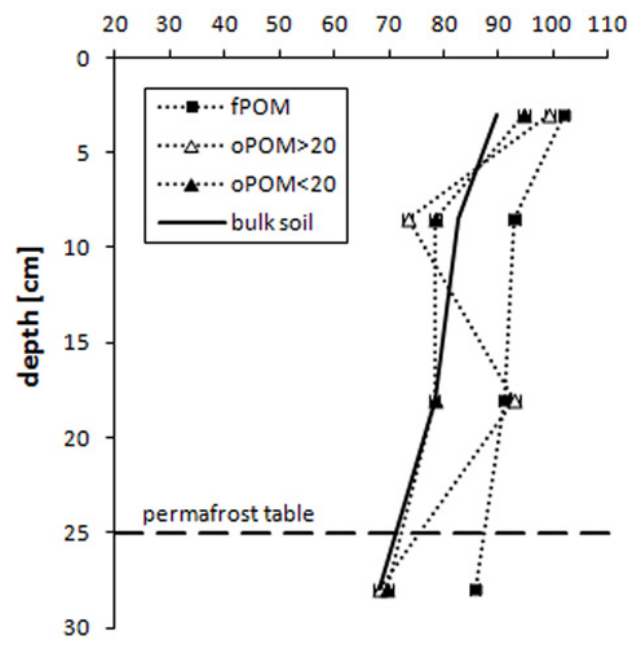

Fig. 2. Distribution of (A) organic carbon content (TOC) in density fractions related to fraction mass and (B) ${ }^{14} \mathrm{C}$ content (one-sigma measurement uncertainties are indicated by bars on each point) over depth.

were highest in surface soil and in $11-25 \mathrm{~cm}$ (17 and $\left.20 \mu \mathrm{g} \mathrm{g}^{-1} \mathrm{DW}\right)$ and lower in the sandy $6-11 \mathrm{~cm}$ layer and in the uppermost still-frozen permafrost layer down to $12 \mu \mathrm{gg}^{-1}$ DW. $n$-fatty acid concentrations in bulk SOM showed an even-over-odd-predominance with $\mathrm{C}_{16}$ and $\mathrm{C}_{24}$ as main compounds and overall concentrations $\left(\mathrm{C}_{14}-\mathrm{C}_{30}\right)$ between $52-255 \mu \mathrm{g} \mathrm{g}^{-1}$ DW (Table 1). The abundance of $\mathrm{C}_{16}$ $n$-fatty acid decreased with depth, whereas $\mathrm{C}_{24}$ concentrations increased in deeper intervals of the active layer and in the adjacent permafrost.

\subsubsection{NMR results and lipid concentration of soil fractions}

${ }^{13}$ C-CPMAS NMR spectroscopy was applied to clay-sized $\mathrm{OM}$ as well as fPOM and $\mathrm{oPOM}=20$; fPOM was measured only from the uppermost layer due to the lack of material. $\mathrm{oPOM}_{<20}$ and the clay fraction showed intensity differences with depth in their aryl and alkyl regions, while O-alkyl and carboxyl signals were within the same range. The dominant functional group of the oPOM $<20$ and clay fractions from all depth intervals was O-alkyl C (e.g. carbohydrates; (KögelKnabner, 2002), which decreased in its abundance with active layer depth (Table 3). Alkyl C (e.g. lipids, suberin, cutin and proteins; Kögel-Knabner, 2002) intensities were slightly higher for the clay fraction (21-28\%) than for the oPOM $<20$ fraction (18-24\%). Larger signals for the aryl C (aromatic carbon; (Baldock et al., 1992) shift region were measured for oPOM $_{<20}(16-24 \%)$ compared to the spectra measured in clay (13-19\%). The carboxyl C signals (e.g. fatty acids, fatty ester; (Baldock et al., 1992) remained constant over depth. The fPOM fraction, which was only analysed in the $0-6 \mathrm{~cm}$ depth interval, showed a considerably different composition with highest abundances of O-alkyl C and lowest of alkyl and carboxyl C.

Lipid concentrations were analysed in four particle size fractions only, as sand fractions were not considered to be important for soil OM stabilization. Total extractable lipids were highest in fine silt and clay (Table 2). $n$-alkanes showed an odd-over-even predominance with the main compounds being $\mathrm{C}_{27}$ and $\mathrm{C}_{29}$ (Fig. 3). Overall, concentrations $\left(\mathrm{C}_{19-}\right.$ $\mathrm{C}_{33}$ ) were highest in the surface soil and in $11-25 \mathrm{~cm}$ (17 and $20 \mu \mathrm{g} \mathrm{g}^{-1} \mathrm{DW}$ ) and lower in the sandy 6-11 $\mathrm{cm}$ layer and in the uppermost still-frozen permafrost layer $\left(12 \mu \mathrm{g} \mathrm{g}^{-1} \mathrm{DW}\right)$. Coarse and medium silt contained extremely low total $n$ alkane concentrations $\left(6-17 \mu \mathrm{g} \mathrm{g}^{-1} \mathrm{DW}\right.$ in $\left.0-6 \mathrm{~cm}\right)$, which decreased further with soil depth. While $n$-alkanes in coarse silt showed no characteristic distribution, medium silt was dominated by $\mathrm{C}_{27}$ and $\mathrm{C}_{29} n$-alkanes (Table 2), which decreased in abundance from about $5 \mu \mathrm{g} \mathrm{g}^{-1} \mathrm{DW}(0-6 \mathrm{~cm})$ to $1 \mu \mathrm{g} \mathrm{g}^{-1} \mathrm{DW}\left(25-30_{\mathrm{p}} \mathrm{cm}\right.$; data not shown). Fine-silt and clay fractions, which were also dominated by $\mathrm{C}_{27}$ and $\mathrm{C}_{29}$ compounds, had higher total $n$-alkane concentrations in all depth intervals than the bulk soil. Medium-chain-length $n$-alkanes $\left(\mathrm{C}_{19}-\mathrm{C}_{24}\right)$ were nearly absent in the coarse and medium-siltsized fractions (data not shown) and occurred in relatively low abundances in fine silt and clay.

Similar to the $n$-alkanes, total $n$-fatty acid concentrations $\left(\mathrm{C}_{14}-\mathrm{C}_{30}\right)$ were extremely low $\left(<10 \mu \mathrm{g} \mathrm{g}^{-1} \mathrm{DW}\right)$ in the coarse- and medium-silt fractions in all depth intervals with no dominant compounds (data not shown), while higher concentrations were determined in fine silt and clay (45$161 \mu \mathrm{g} \mathrm{g}^{-1} \mathrm{DW}$ ), with $\mathrm{C}_{16}$ and $\mathrm{C}_{24} n$-fatty acids being the most abundant compounds (Fig. 4). The dominance of the $\mathrm{C}_{16} n$-fatty acid in fine silt and clay decreased with depth and 
Table 3. Relative contents [\%] of chemical structures identified by ${ }^{13} \mathrm{C}$-CPMAS NMR spectroscopy in the clay fraction $(<2 \mu \mathrm{m})$ and in free (fPOM) and occluded particulate organic matter $<20 \mu \mathrm{m}\left(\mathrm{oPOM}_{<20}\right)$.

\begin{tabular}{lccccccc}
\hline Fraction & Depth $[\mathrm{cm}]$ & Alkyl C & O-alkyl C & Aryl C & Carboxyl C & Alkyl C/O-alkyl C & Aryl C/O-alkyl C \\
\hline fPOM & $0-6$ & 15 & 56 & 24 & 6 & 0.27 & 0.42 \\
\hline oPOM $_{<20}$ & $0-6$ & 21 & 52 & 16 & 12 & 0.40 & 0.30 \\
& $6-11$ & n.d. & n.d. & n.d. & n.d. & n.d. & n.d. \\
& $11-25$ & 18 & 47 & 24 & 12 & 0.39 & 0.51 \\
& $25-30 \mathrm{p}$ & 24 & 40 & 24 & 12 & 0.59 & 0.60 \\
\hline clay & $0-6$ & 23 & 51 & 13 & 14 & 0.45 & 0.25 \\
& $6-11$ & 21 & 50 & 19 & 11 & 0.41 & 0.37 \\
& $11-25$ & 24 & 49 & 17 & 10 & 0.48 & 0.34 \\
& $25-30 \mathrm{p}$ & 28 & 43 & 15 & 13 & 0.65 & 0.35 \\
\hline
\end{tabular}

shifted to $\mathrm{C}_{24}$, which is the most abundant compound in the uppermost permafrost still-frozen layer. In these two fractions total $n$-fatty acid concentrations decreased with depth within the active layer $(0-25 \mathrm{~cm})$, but increase again to concentrations twice as high in the frozen soil layer $\left(25-30_{\mathrm{p}} \mathrm{cm}\right)$. This increase mainly resulted from higher abundances of compounds with $>\mathrm{C}_{20}$ chain length.

The $n$-alkane concentrations in the fPOM, oPOM ${ }_{>20}$ and $\mathrm{oPOM}_{<20}$ fractions were generally higher (15$\left.98 \mu \mathrm{gg}^{-1} \mathrm{DW}\right)$ than in the bulk soil $\mathrm{OM}$ and particle size fractions, and yielded high abundances of medium-chainlength compounds $\left(\mathrm{C}_{19}-\mathrm{C}_{24}\right)$ representing $33-55 \%$ of the overall concentration. Highest $n$-alkane concentrations were measured in $\mathrm{oPOM}_{<20}$ from all depth intervals. Concentration increased with active layer depth in all three fractions, but dropped in the frozen soil layer $\left(25-30_{\mathrm{p}} \mathrm{cm}\right)$ in $\mathrm{fPOM}$ and $\mathrm{oPOM}<20$ fractions (Fig. 3). fPOM and $\mathrm{oPOM}<20$ were dominated by $\mathrm{C}_{23}$ and the long-chain compounds $\mathrm{C}_{27}$ and $\mathrm{C}_{29}$, while oPOM$>20$ mainly contained $n$-alkanes of medium chain length centring around $\mathrm{C}_{23}$.

$n$-fatty acid concentrations of all density fractions (0.1$256.5 \mathrm{~g} \mathrm{~g} \mathrm{~g}^{-1} \mathrm{DW}$ ) were one order of magnitude higher compared to $n$-alkanes $\left(0.0-18.4 \mu \mathrm{g} \mathrm{g}^{-1} \mathrm{DW}\right)$, particularly in fPOM for the uppermost two depth intervals, and had a clear even-over-odd predominance (Fig. 4). Overall, concentrations $\left(\mathrm{C}_{14}-\mathrm{C}_{30}\right)$ varied between 90 and $1129 \mu \mathrm{g} \mathrm{g}^{-1} \mathrm{DW}$ and increased with depth in the $\mathrm{oPOM}_{>20}$ fraction (from 103 to $625 \mu \mathrm{g} \mathrm{g}^{-1} \mathrm{DW}$ ). The fPOM and $\mathrm{oPOM}_{<20}$ fractions yielded highest $n$-fatty acid concentrations in the sandy depth interval $(6-11 \mathrm{~cm})$ with 1129 and $395 \mu \mathrm{g} \mathrm{g}{ }^{-1} \mathrm{DW}$, respectively (Table 2). The dominant compounds in all fractions in the two surface layers were $\mathrm{C}_{16}$ and $\mathrm{C}_{18} n$-fatty acids. Compound distributions changed with depth to longer chain length, with $\mathrm{C}_{24}$ being the major compound in $\mathrm{oPOM}_{>20}$ and $\mathrm{oPOM}_{<20}$ at $11-30_{\mathrm{p}} \mathrm{cm}$. In the still-frozen depth interval, highest total $n$-fatty acid concentrations were present in $\mathrm{oPOM}_{>20}$, which contained predominantly long-chain compounds $\left(\mathrm{C}_{24}-\mathrm{C}_{30}\right)$.

\subsection{Radiocarbon contents of soil fractions}

The various soil fractions showed decreasing ${ }^{14} \mathrm{C}$ contents towards larger fraction size and greater soil depth (Figs. 1b and $2 \mathrm{~b}$ ). Fine silt and clay had similar ${ }^{14} \mathrm{C}$ contents like bulk $\mathrm{OM}$ and also comparable values over all depth intervals (Fig. 1b), which were slightly higher (71-94 pMC) than concentrations of bulk OM (68-90 pMC). The medium-silt fraction had lower ${ }^{14} \mathrm{C}$ contents (54-82 pMC) than fine-silt and clay fractions and bulk OM. Lowest ${ }^{14} \mathrm{C}$ contents were measured in the coarse-silt fractions, which decreased most strongly with depth down to $24 \mathrm{pMC}$ in the uppermost permafrost layer $\left(25-30_{\mathrm{p}} \mathrm{cm}\right)$. This fraction had the lowest contents of all analysed fractions.

The three density fractions also showed decreasing ${ }^{14} \mathrm{C}$ contents in the order fPOM $>$ oPOM $>20>0 P O M<20$ and a decrease with soil depth (Fig. 2b), but concentrations were slightly higher in both surface layers than in bulk soil OM. The highest ${ }^{14} \mathrm{C}$ contents and the smallest decrease with depth from 102 to $86 \mathrm{pMC}$ was measured for the PPOM fraction. The oPOM fractions decreased more strongly in ${ }^{14} \mathrm{C}$ content with depth, except for a higher value for $\mathrm{oPOM}_{>20}$ from $11-25 \mathrm{~cm}$ soil depth, and yielded lowest values in the frozen layer, which are similar to that of the bulk soil.

\section{Discussion}

\subsection{Distribution and composition of bulk soil organic matter}

We found considerable differences of the physical and chemical soil properties in the shallow active layer thawing during summer $(0-25 \mathrm{~cm})$ and the uppermost still-frozen permafrost $\left(25-30_{\mathrm{p}} \mathrm{cm}\right)$ of a polygonal rim on Samoylov Island (Table 2). The distribution of the separated particle size fractions revealed changes in the textural composition from the two near surface intervals $(0-6 \mathrm{~cm}$ and $6-11 \mathrm{~cm})$ dominated by sand-sized material (60\%) to the two lower horizons (11-25 


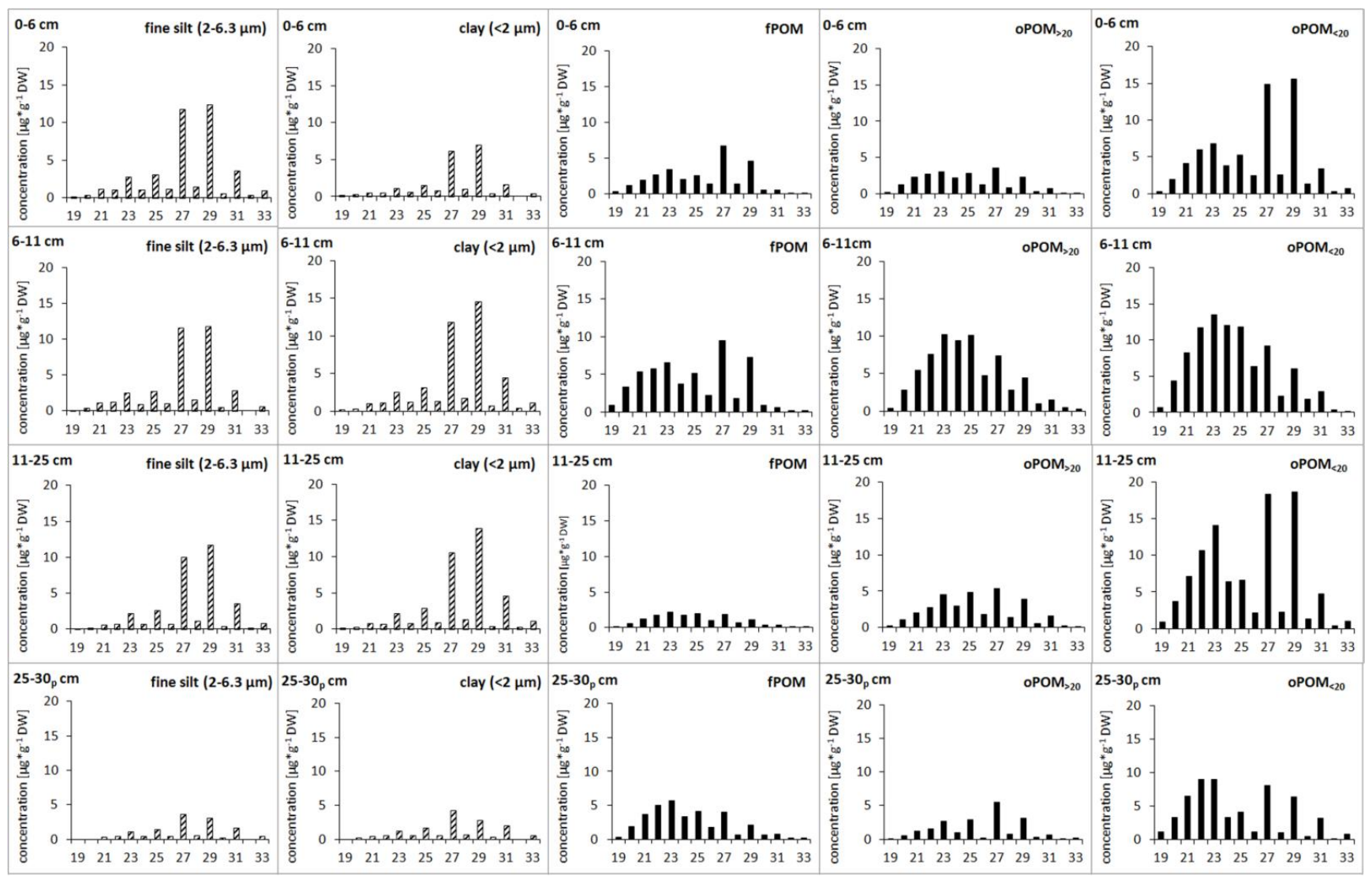

Fig. 3. $n$-alkane concentrations in fine silt and clay (striped bars) and in three density fractions (black bars) from different depths intervals. Only odd $n$-alkanes are labelled on the $\mathrm{x}$-axis.

and $25-30 \mathrm{p} \mathrm{cm}$;), which contained more than $65 \%$ silt and clay-sized material. High sand contents are most probably of aeolian origin eroded from the sandbanks of the Lena Delta (Hubberten et al., 2006). Differences in soil texture in the surface soil and near the permafrost table may be explained by soil-developing processes like physical weathering and vertical translocation of fine-grained particles. Intense freezingthawing cycles as well as the breakup of particles by cryohydration occurring in cold climates may produce fine-grained particles (Jones et al., 2010).

Changes in chemical soil properties in the active layer are reflected by the elemental composition and, in more detail, by the molecular analyses of organic compounds and structures. The TOC contents in the active layer of the polygonal rim (on average $2.5 \%$; Table 1) are characteristic for OM in tundra soil developed in Holocene fluvial deposits in this area (Zimov et al., 2006; Wagner et al., 2007; Xu et al., 2009). The relatively high $\mathrm{C} / \mathrm{N}$ ratios around 18 most likely reflect the slow transformation of the $\mathrm{OM}$ at cold temperatures and indicate the presence of little-decomposed OM. Likewise, the high and rapidly, nearly linearly, increasing apparent ${ }^{14} \mathrm{C}$ ages of bulk OM with depth (866-3052 yr BP; Table 1) suggest slow organic carbon turnover and the accumu- lation of "old" material, respectively, and no significant mixing by cryoturbation. We did not expect such low ${ }^{14} \mathrm{C}$ values in the shallow active layer since previous results, which were however determined for OM from permafrost cores from Samoylov Island, were around $2300 \mathrm{yrBP}$ in $289 \mathrm{~cm}$ and $7900 \mathrm{yr} \mathrm{BP}$ in $557 \mathrm{~cm}$ (Wagner et al., 2007). Instead, quite similar ${ }^{14} \mathrm{C}$ results were determined for $\mathrm{OM}$ in the active layer of tundra soils in Russia $\left(66^{\circ} \mathrm{N}, 42^{\circ} \mathrm{E}\right)$ and on Svalbard $\left(78-79^{\circ} \mathrm{N}, 13-17^{\circ} \mathrm{E}\right)$, Norway, with ${ }^{14} \mathrm{C}$ concentrations declining from modern values to about $53 \mathrm{pMC}$ equivalent to $5100 \mathrm{yrs}$ BP in the upper $40 \mathrm{~cm}$ of soils from various sites (Cherkinsky, 1996) and for OM of three active layers (35$50 \mathrm{~cm})$ from sites in Alaska $\left(64-67^{\circ} \mathrm{N}, 147-150^{\circ} \mathrm{W}\right)$ with ${ }^{14} \mathrm{C}$ ages between 585 and $3363 \mathrm{yr} \mathrm{BP}$ (Waldrop et al., 2010).

The $n$-alkane distribution in bulk OM (Table 1) suggests that a major portion in all depth intervals is plant-derived material indicated by $\mathrm{C}_{27}$ and $\mathrm{C}_{29} n$-alkanes being the most abundant compounds, which are major compounds of epicuticular waxes (Eglinton and Hamilton, 1967) frequently used as biomarkers for higher plant input to soils and aquatic sediments (e.g. Jambu et al., 1991; Huang et al., 2000). Likewise, the $n$-fatty acid distribution maximizing at $\mathrm{C}_{24}$ reflects the terrestrial plant origin of $\mathrm{OM}$ in the two surface soil layers 


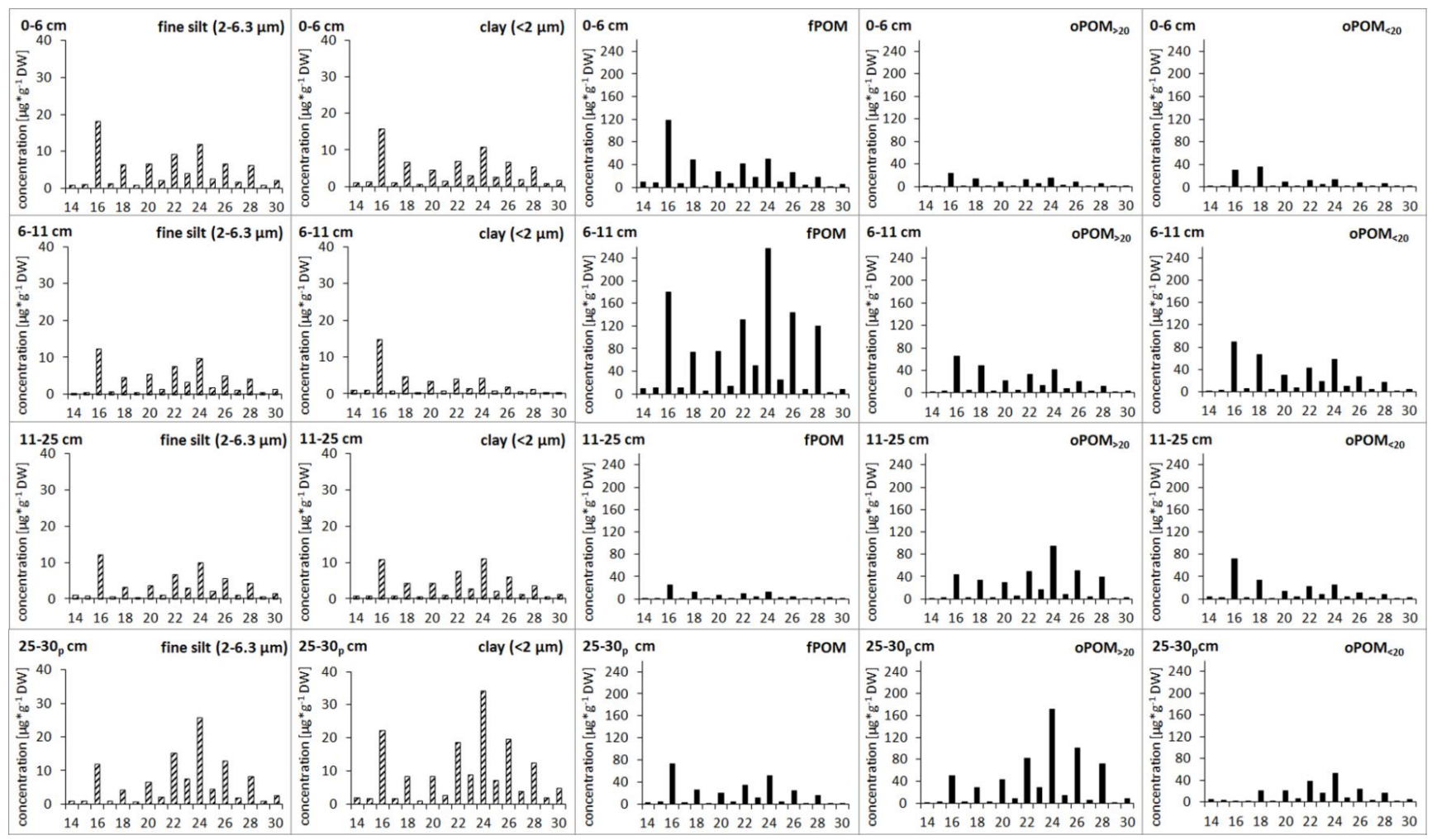

Fig. 4. Distribution of $n$-fatty acids in fine silt and clay (striped) and in density fractions (black) from different depths intervals. Only even $n$-fatty acids are labelled on the $\mathrm{x}$-axis; note different scaling of $\mathrm{y}$-axis.

(0-11 cm; data not shown). Since lipid concentrations were found to correlate with TOC contents (Naafs et al., 2004), the strong increase in concentrations of the long-chain $n$-fatty acid compounds in the lowermost active layer interval and in still-frozen soil may result from inputs of other sources than plant material at greater depth or more likely, from in situ secondary production by the transformation of plant wax esters or root-derived polyesters and suberin (Ficken et al., 1998; Bull et al., 2000; Andersson and Meyers, 2012).

In summary, relatively high $\mathrm{C} / \mathrm{N}$ values and abundances of long-chain $n$-alkanes in the active layer and adjacent upper permafrost layer reflected that soil OM consisted of littledegraded plant material. This result is in contrast to the high and increasing apparent ${ }^{14} \mathrm{C}$ ages with active layer depth, which is generally considered to result from the accumulation of strongly transformed, "old" organic matter (Rumpel and Kögel-Knabner, 2011). However, little-degraded, "old" plant material in the depth intervals near the permafrost table may be protected against biodegradation by preservation mechanisms like interaction with clay particles, which increase in abundances in these layers.

\subsection{Stabilization mechanisms of SOM}

Three mechanisms are known to be relevant for OM stability in temperate soils; these are (a) formation of soil aggre- gates, (b) formation of organo-mineral associations, and (c) the chemical recalcitrance of organic compounds (Sollins et al., 1996; Christensen, 2001; Six et al., 2002; Baldock et al., 2004; Kögel-Knabner et al., 2008). However, so far it is not known if these mechanisms are relevant, and if so, which of them is of primary importance in the active layer of Arctic soils. Since reduced bioaccessibility of OM in soil aggregates and of organo-mineral assemblages was found to be of major importance for OM preservation in various temperate soils (Sollins et al., 2006; Marschner et al., 2008; Sanaullah et al., 2011), we analysed the composition of OM in ${ }^{14} \mathrm{C}$ dated particle size and density factions from depth intervals of the active layer and uppermost still-frozen soil of the polygonal rim to get information about OM sources and protection mechanisms.

\subsubsection{Organic matter in soil aggregates}

The fractions, fPOM, oPOM $>20$ and $\mathrm{oPOM}_{<20}$ separated by density fractionation, showed strong differences in their distribution and chemical composition in the active layer $(0-25 \mathrm{~cm})$ and the uppermost still-frozen permafrost $\left(25-30_{\mathrm{p}} \mathrm{cm}\right)$. Similar to previous studies, fPOM material had higher ${ }^{14} \mathrm{C}$ contents and thus presumably also a faster turnover than oPOM material (Quideau et al., 2000; Rethemeyer et al., 2005; von Lützow et al., 2007; Trumbore, 2009), 
which was attributed to stabilization due to occlusion in aggregates and the recalcitrance of organic components in this fraction (Golchin et al., 1997; Poirier et al., 2005). In general, the POM material from all depth intervals is mainly derived from higher plants as indicated by $n$-alkane distributions dominated by odd numbered plant-derived $\mathrm{C}_{23}$ to $\mathrm{C}_{29}$ compounds (Eglinton and Hamilton, 1967).

The three fractions, however, showed strong compositional differences between each other and with soil depth. The light fPOM fraction, which is not occluded in aggregated soil structures, representing slightly decomposed root and plant material (Golchin et al., 1994), was the most abundant and carbon-rich fraction in the surface soil $(0-6 \mathrm{~cm})$, but decreased rapidly in abundance with active layer depth (Fig. 2a). The composition of fPOM material changed with depth from carbohydrate-rich (O-alkyl C; Table 3) material to more strongly decomposed plant litter as suggested by decreasing $\mathrm{C} / \mathrm{N}$ ratios (Table 2). However, the absence of the dominant long-chain $n$-alkanes $\left(\mathrm{C}_{27}\right.$ and $\left.\mathrm{C}_{29}\right)$ below $11 \mathrm{~cm}$ soil depth may also reflect a change in fPOM sources like decreasing proportions of plant leaf wax compounds and higher amounts of still relatively "young" root-derived OM.

Organic matter occluded in soil aggregates, which was released upon sonication, increased in importance in regard to carbon storage near and below the permafrost table (Fig. 2a). Both oPOM fractions, $<20 \mu \mathrm{m}$ and $>20 \mu \mathrm{m}$, showed a quite similar and stronger ${ }^{14} \mathrm{C}$ decrease with depth compared to the small ${ }^{14} \mathrm{C}$ decrease in $\mathrm{PPOM}$ material, presumably indicative for better preservation of OM occluded in soil aggregates (Golchin et al., 1997). The high value for $\mathrm{oPOM}_{>20}$ from $11-25 \mathrm{~cm}$ may be biased by the presence of larger plant or root fragments. Despite quite similar ${ }^{14} \mathrm{C}$ values, both oPOM fractions showed considerable compositional differences. Surprisingly, the composition of the large $\mathrm{oPOM}_{>20}$ fraction obtained after aggregate disruption is quite similar to that of fPOM material, both being little-decomposed, plant-derived $\mathrm{OM}$ with high $\mathrm{C} / \mathrm{N}$ ratios around 30 decreasing slightly with depth. The dominance of medium-chainlength $n$-alkanes and the lack of long-chain compounds in oPOM $_{>20}\left(C_{27}\right.$ and $\left.C_{29}\right)$, however, suggest either stronger OM transformation or different plant sources contribution to $\mathrm{OM}$ in this fraction.

In contrast, $\mathrm{OM}$ in the small $\mathrm{oPOM}_{<20}$ fraction is apparently derived from other sources since typical leaf waxderived $\mathrm{C}_{27}$ and $\mathrm{C}_{29} n$-alkanes were dominant compounds in most depth intervals. Declining abundances of O-alkyl C (carbohydrate-rich material) and higher proportions of aryl $\mathrm{C}$ (aromatic compounds) as well as increasing alkyl C/O-alkyl C (Baldock et al., 1992) and aryl C/O-alkyl C ratios (Quideau et al., 2000) with depth suggest a stronger transformation of small OM occluded in aggregates, which was also found in temperate soils (Mueller and Koegel-Knabner, 2009).

The lower ${ }^{14} \mathrm{C}$ values and higher TOC content of oPOM compared to $\mathrm{PPOM}$ suggest that aggregate formation may play a small but significant role for OM preservation in these
Arctic soils, however only at greater active layer depth. The effect seems to be not as prominent as in temperate surface soils under grassland and forest, where oPOM fractions were shown to account for around $5 \%$ of the soil mass, but contained over $30 \%$ of the bulk soil TOC (Mueller and KoegelKnabner, 2009). In this study the oPOM fractions from the active layer had a cumulative mass of about $1 \%$ containing $0.9-3.9 \mathrm{mg} \mathrm{C} \mathrm{g}^{-1} \mathrm{DW}$ (8-16\% of total soil TOC) (Table 2; Fig. 2a).

\subsubsection{Organo-mineral associations}

Although the uppermost $11 \mathrm{~cm}$ of the active layer were dominated by sand-sized material, most organic carbon was stored in the clay and fine-silt fractions $(<6.3 \mu \mathrm{m})$ containing up to $15.3 \mathrm{mg} \mathrm{C} \mathrm{g}^{-1}$ DW (62\% of the total soil TOC) and increasing in importance with depth (Fig. 1a; Table 2). This is quite similar to results for temperate soils where clay and silt fractions also had highest TOC contents of above $65 \%$ (Flessa et al., 2008) and above 50\% (Rumpel et al., 2004). The ${ }^{14} \mathrm{C}$ contents of the size fractions showed a surprising trend from highest values for fine silt and clay-sized OM, which were close to that of bulk OM, to extremely low values for coarse silt $(20-63 \mu \mathrm{m})$. This is in contrast to results of most previous studies of temperate soils, where often clay- to silt-sized OM $(<63 \mu \mathrm{m})$ both had relatively low ${ }^{14} \mathrm{C}$ contents, while sandsized material (200-2000 $\mu \mathrm{m})$ often showed highest ${ }^{14} \mathrm{C}$ values (Schöning and Kögel-Knabner, 2006; Sollins et al., 2006; von Lützow et al., 2007). Presumably, the very low ${ }^{14} \mathrm{C}$ contents of coarse silt may be affected by preserved POM artefacts in micro-aggregate structures.

More intense transformation of OM with decreasing particle size was observed in the uppermost $11 \mathrm{~cm}$ of the active layer, where $\mathrm{C} / \mathrm{N}$ values decreased from sand to clay. However this trend, which was also observed in numerous previous studies of temperate soils and was often attributed to enrichment of microbial reworked products in fine mineral fractions (Sollins et al., 2006; von Lützow et al., 2007; Flessa et al., 2008; Bol et al., 2009; Sollins et al., 2009), is not seen in deeper sampling intervals. Here, closely alike $\mathrm{C} / \mathrm{N}$ ratios of coarse silt to clay-sized material $(<63 \mu \mathrm{m})$ suggest a similar transformed OM. The decomposition degree of OM in fine silt and clay slightly increased with depth as shown by decreasing $\mathrm{C} / \mathrm{N}$ ratios and increasing alkyl $\mathrm{C} / \mathrm{O}$-alkyl $\mathrm{C}$ ratios in the clay fraction. These results reflect that the labile O-alkyl C structures like carbohydrates are less stabilized, as described already for temperate soils (Rumpel et al., 2004).

Fine silt and clay showed a very similar $n$-alkane and $n$ fatty acid distributions as well as ${ }^{14} \mathrm{C}$ values in the different depth intervals. The plant source of soil OM in the fine-silt and clay fraction did not change significantly over depth, as indicated by $n$-alkanes being dominated by leaf wax-derived $\mathrm{C}_{27}$ and $\mathrm{C}_{29}$. The increase of $n$-fatty acid concentration in the uppermost permafrost layer $\left(25-30_{\mathrm{p}} \mathrm{cm}\right)$ compared to the concentration in the active layer are most likely the result of 
in situ production by the hydrolysis of plant wax esters into its component $n$-alkanols and $n$-fatty acids or contribution of root-derived polyesters and suberin (Ficken et al., 1998).

Despite the lower ${ }^{14} \mathrm{C}$ contents of coarse and medium-silt fractions $(6.3-63 \mu \mathrm{m})$ they are less important for organic carbon storage as both fractions represented very little of the total soil TOC ( $<2 \mathrm{mg} \mathrm{Cg}^{-1}$ DW, Fig. 1a). The sand fractions (63-200 $\mu \mathrm{m}$ and 200-2000 $\mu \mathrm{m}$ ) were considered to be not important for carbon storage or soil OM stabilization as these fractions contain hardly any carbon $\left(<0.3 \mathrm{mg} \mathrm{C} \mathrm{g}^{-1} \mathrm{DW}\right)$.

\section{Conclusions}

Organic matter in the active layer of a polygon rim was dominated by only slightly decomposed, mainly higher plantderived material with relatively high and strongly increasing apparent ${ }^{14} \mathrm{C}$ ages. In temperate soils high ${ }^{14} \mathrm{C}$ ages have been assumed to reflect the accumulation and stabilization of strongly transformed OM with depth. There, the formation of organo-mineral associations has been thought to be the most important mechanisms for OM stabilization. The results of our model study suggest that this mechanism is less important for OM preservation in the active layer of permafrost soils, indicated by lower organic carbon contents of clayand fine-silt-sized OM compared to density-fractionated occluded POM (representing organic material occluded in aggregates). A further indicator is the younger apparent ${ }^{14} \mathrm{C}$ contents of clay- and fine-silt-sized OM compared to values for the bulk soil. Despite the high TOC contents of occluded POM from all depth intervals, protection of OM in soil aggregates seems to be a mechanism which is important only at greater active layer depth suggested by relatively high ${ }^{14} \mathrm{C}$ values in the uppermost $6 \mathrm{~cm}$ and low values near the permafrost table compared to the free light POM fraction. These results suggest that other mechanisms like recalcitrance of soil OM compounds defined by its chemical composition and decomposability, which was thought to be of minor importance for OM preservation in temperate soils, may play a more important role in permafrost soil. Therefore, further research is needed to evaluate the importance of the chemical recalcitrance of OM in the active layer as well as the climatic stabilization due to low temperatures.

Acknowledgements. The authors thank Stefan Heinze and Lukas Wacker for AMS ${ }^{14} \mathrm{C}$ measurements and Benedict Behr-Heyer, Sophia Burghardt and Sven Gelking for their assistance during night shifts. Maria Greiner, Svetlana König, Bianca Stapper and Ulrike Patt are thanked for their assistance with sample preparation and Sebastian Zubrzycki for his help with soil sampling. Gesine Mollenhauer is thanked for providing soil material. We are also grateful for logistical support by the Alfred Wegener Institute, in particular by Waldemar Schneider and Günther Stoof. We also thank two anonymous reviewers for their constructive suggestions.
Edited by: I. Bussmann

\section{References}

Akerman, H. J. and Johansson, M.: Thawing Permafrost and Thicker Active Layers in Sub-arctic Sweden, Permafrost Periglac., 19, 279-292, doi:10.1002/ppp.626, 2008.

Andersson, R. A. and Meyers, P. A.: Effect of climate change on delivery and degradation of lipid biomarkers in a Holocene peat sequence in the Eastern European Russian Arctic, Org. Geochem., 53, 63-72, doi:10.1016/j.orggeochem.2012.05.002, 2012.

Anisimov, O. and Reneva, S.: Permafrost and Changing Climate: The Russian Perspective, AMBIO: A Journal of the Human Environment, 35, 169-175, 2006.

Are, F. and Reimnitz, E.: An Overview of the Lena River Delta Setting: Geology, Tectonics, Geomorphology, and Hydrology, J. Coastal Res., 16, 1083-1093, 2000.

Arnarson, T. S. and Keil, R. G.: Changes in organic mattermineral interactions for marine sediments with varying oxygen exposure times, Geochim. Cosmochim. Ac., 71, 3545-3556, doi:10.1016/j.gca.2007.04.027, 2007.

Baldock, J. A., Oades, J. M., Waters, A. G., Peng, X., Vassallo, A. M., and Wilson, M. A.: Aspects of the chemical structure of soil organic materials as revealed by solid-state 13C NMR spectroscopy, Biogeochemistry, 16, 1-42, doi:10.1007/bf02402261, 1992.

Baldock, J. A., Masiello, C. A., Gélinas, Y., and Hedges, J. I.: Cycling and composition of organic matter in terrestrial and marine ecosystems, Mar. Chem., 92, 39-64, 2004.

Biasi, C., Rusalimova, O., Meyer, H., Kaiser, C., Wanek, W., Barsukov, P., Junger, H., and Richter, A.: Temperature-dependent shift from labile to recalcitrant carbon sources of arctic heterotrophs, Rapid Commun. Mass Sp., 19, 1401-1408, 2005.

Boike, J., Abramova, K., Bolshiyanov, D. Y., Grigoriev, M. N., Herzschuh, U., Kattner, G., Knoblauch, C., Kutzbach, L., Mollenhauer, G., and Schneider, W.: Russian-German Cooperation SYSTEM LAPTEV SEA: The Expedition Lena 2009, Alfred Wegener Institute for Polar and Marine Research, Bremerhaven, Germany, 34 pp., 2009.

Boike, J., Kattenstroth, B., Abramova, K., Bornemann, N., Chetverova, A., Fedorova, I., Fröb, K., Grigoriev, M., Grüber, M., Kutzbach, L., Langer, M., Minke, M., Muster, S., Piel, K., Pfeiffer, E.-M., Stoof, G., Westermann, S., Wischnewski, K., Wille, C., and Hubberten, H.-W.: Baseline characteristics of climate, permafrost, and land cover from a new permafrost observatory in the Lena River Delta, Siberia (1998-2011), Biogeosciences Discuss., 9, 13627-13684, doi:10.5194/bgd-9-136272012, 2012.

Bol, R., Poirier, N., Balesdent, J., and Gleixner, G.: Molecular turnover time of soil organic matter in particle-size fractions of an arable soil, Rapid Commun. Mass Sp., 23, 2551-2558, doi:10.1002/rcm.4124, 2009.

Bull, I. D., van Bergen, P. F., Nott, C. J., Poulton, P. R., and Evershed, R. P.: Organic geochemical studies of soils from the Rothamsted classical experiments $-\mathrm{V}$. The fate of lipids in different long-term experiments, Org. Geochem., 31, 389-408, 2000.

Charkin, A. N., Dudarev, O. V., Semiletov, I. P., Kruhmalev, A. V., Vonk, J. E., Sánchez-García, L., Karlsson, E., and Gustafsson, Ö.: Seasonal and interannual variability of sedimentation 
and organic matter distribution in the Buor-Khaya Gulf: the primary recipient of input from Lena River and coastal erosion in the southeast Laptev Sea, Biogeosciences, 8, 2581-2594, doi:10.5194/bg-8-2581-2011, 2011.

Cherkinsky, A. E.: 14C dating and soil organic matter dynamcis in arctic and subarctic ecosystems, Radiocarbon, 38, 241-245, 1996.

Christensen, B. T.: Physical fractionation of soil and structural and functional complexity in organic matter turnover, Eur. J. Soil Sci., 52, 345-353, doi:10.1046/j.1365-2389.2001.00417.x, 2001.

Dickens, A. F., Baldock, J. A., Smernik, R. J., Wakeham, S. G., Arnarson, T. S., Gélinas, Y., and Hedges, J. I.: Solid-state 13C NMR analysis of size and density fractions of marine sediments: Insight into organic carbon sources and preservation mechanisms, Geochim. Cosmochim. Ac., 70, 666-686, 2006.

Dittmar, T. and Kattner, G.: The biogeochemistry of the river and shelf ecosystem of the Arctic Ocean: a review, Mar. Chem., 83, 103-120, doi:10.1016/S0304-4203(03)00105-1, 2003.

Eglinton, G. and Hamilton, R. J.: Leaf epicuticular waxes, Science, 156, 1322-1335, 1967.

Fahl, K. and Stein, R.: Biomarker records, organic carbon accumulation, and river discharge in the Holocene southern Kara Sea (Arctic Ocean), Geo-Mar. Lett., 27, 13-25, doi:10.1007/s00367006-0049-8, 2007.

FAO - Food and Agriculture Organization: WRB - World reference base for soil resources 2006, 1st update 2007, FAO, Rom, 1-128, 2007.

Ficken, K. J., Barber, K. E., and Eglinton, G.: Lipid biomarker, $\delta 13 \mathrm{C}$ and plant macrofossil stratigraphy of a Scottish montane peat bog over the last two millennia, Org. Geochem., 28, 217237, 1998.

Flessa, H., Amelung, W., Helfrich, M., Wiesenberg, G. L. B., Gleixner, G., Brodowski, S., Rethemeyer, J., Kramer, C., and Grootes, P. M.: Storage and stability of organic matter and fossil carbon in a Luvisol and Phaeozem with continuous maize cropping: A synthesis, J. Plant Nutr. Soil Sc., 171, 36-51, doi:10.1002/jpln.200700050, 2008.

Frey, K. E. and McClelland, J. W.: Impacts of permafrost degradation on arctic river biogeochemistry, Hydrol. Process., 23, 169182, doi:10.1002/hyp.7196, 2009.

Golchin, A., Oades, J., Skjemstad, J., and Clarke, P.: Study of free and occluded particulate organic matter in soils by solid state ${ }^{13} \mathrm{C}$ CP/MAS NMR spectroscopy and scanning electron microscopy, Soil Research, 32, 285-309, doi:10.1071/SR9940285, 1994.

Golchin, A., Baldock, J. A., and Oades, J. M.: A model linking organic matter decomposition, chemistry and aggregate dynamics, in: Soil Processes and the Carbon Cycle, edited by: Stewart, B. A. E., CRC Press, Boca Raton, FL, 245-266, 1997.

Guicharnaud, R., Arnalds, O., and Paton, G. I.: Short term changes of microbial processes in Icelandic soils to increasing temperatures, Biogeosciences, 7, 671-682, doi:10.5194/bg-7-671-2010, 2010.

Guo, L., Ping, C.-L., and Macdonald, R. W.: Mobilization pathways of organic carbon from permafrost to arctic rivers in a changing climate, Geophys. Res. Lett., 34, L13603, doi:10.1029/2007g1030689, 2007.

Gustafsson, Ö., van Dongen, B. E., Vonk, J. E., Dudarev, O. V., and Semiletov, I. P.: Widespread release of old carbon across the Siberian Arctic echoed by its large rivers, Biogeosciences,
8, 1737-1743, doi:10.5194/bg-8-1737-2011, 2011.

Hinkel, K. M. and Nelson, F. E.: Spatial and temporal patterns of active layer thickness at Circumpolar Active Layer Monitoring (CALM) sites in northern Alaska, 1995-2000, J. Geophys. Res., 108, 8168-8181, doi:10.1029/2001JD000927, 2003.

Huang, Y. S., Dupont, L., Sarnthein, M., Hayes, J. M., and Eglinton, G.: Mapping of C4 plant input from North West Africa into North East Atlantic sediments, Geochim. Cosmochim. Ac., 64, 35053513, 2000.

Hubberten, H.-W., Wagner, D., Pfeiffer, E.-M., Boike, J., and Gukov, A. Y.: The Russian-German research station Samoylov, Lena Delta - A key site for polar research in the Siberian Arctic, Polarfoschung, 73, 111-116, 2006.

Jambu, P., Amblès, A., Dinel, H., and Secouet, B.: Incorporation of natural hydrocarbons from plant residues into an hydromorphic humic podzol following afforestation and fertilization, J. Soil Sci., 42, 629-636, 1991.

Jones, A., Stolbovoy, V., Tarnocai, C., Broll, G., Spaargaren, O., and Montanarella, L.: Soil Atlas of the northern circumpolar region, European Commission, Publications Office of the European Union, Luxembourg, 2010.

Karlsson, E. S., Charkin, A., Dudarev, O., Semiletov, I., Vonk, J. E., Sánchez-García, L., Andersson, A., and Gustafsson, Ö.: Carbon isotopes and lipid biomarker investigation of sources, transport and degradation of terrestrial organic matter in the Buor-Khaya Bay, SE Laptev Sea, Biogeosciences, 8, 1865-1879, doi:10.5194/bg-8-1865-2011, 2011.

Knoblauch, C., Zimmermann, U., Blumenberg, M., Michaelis, W., and Pfeiffer, E.-M.: Methane turnover and temperature response of methane-oxidizing bacteria in permafrost-affected soils of northeast Siberia, Soil Biol. Biochem., 40, 3004-3013, 2008.

Kögel-Knabner, I.: Analytical approaches for characterizing soil organic matter, Org. Geochem., 31, 609-625, 2000.

Kögel-Knabner, I.: The macromolecular organic composition of plant and microbial residues as inputs to soil organic matter, Soil Biol. Biochem., 34, 139-162, 2002.

Kögel-Knabner, I., Guggenberger, G., Kleber, M., Kandeler, E., Kalbitz, K., Scheu, S., Eusterhues, K., and Leinweber, P.: Organo-mineral associations in temperate soils: Integrating biology, mineralogy, and organic matter chemistry, J. Plant Nutr. Soil Sc., 171, 61-82, doi:10.1002/jpln.200700048, 2008.

Kutzbach, L., Wagner, D., and Pfeiffer, E.-M.: Effect of microrelief and vegetation on methane emission from wet polygonal tundra, Lena Delta, Northern Siberia, Biogeochemistry, 69, 341-362, doi:10.1023/B:BIOG.0000031053.81520.db, 2004.

Lara, R. J., Rachold, V., Kattner, G., Hubberten, H. W., Guggenberger, G., Skoog, A., and Thomas, D. N.: Dissolved organic matter and nutrients in the Lena River, Siberian Arctic: Characteristics and distribution, Mar. Chem., 59, 301-309, 1998.

Lobbes, J. M., Fitznar, H. P., and Kattner, G.: Biogeochemical characteristics of dissolved and particulate organic matter in Russian rivers entering the Arctic Ocean, Geochim. Cosmochim. Ac., 64, 2973-2983, 2000.

Marschner, B., Brodowski, S., Dreves, A., Gleixner, G., Gude, A., Grootes, P. M., Hamer, U., Heim, A., Jandl, G., Ji, R., Kaiser, K., Kalbitz, K., Kramer, C., Leinweber, P., Rethemeyer, J., Schäffer, A., Schmidt, M. W. I., Schwark, L., and Wiesenberg, G. L. B.: How relevant is recalcitrance for the stabilization of organic matter in soils?, J. Plant Nutr. Soil Sc., 171, 91-110, 
doi:10.1002/jpln.200700049, 2008.

Minke, M., Donner, N., Karpov, N. S., Klerk, P. D., and Joosten, H.: Distribution, diversity, development and dynamics of polygon mires: examples from Northeast Yakutia (Siberia), Peatlands International, 1, 36-40, 2007.

Mueller, C. and Koegel-Knabner, I.: Soil organic carbon stocks, distribution, and composition affected by historic land use changes on adjacent sites, Biol. Fert. Soils, 45, 347-359, doi:10.1007/s00374-008-0336-9, 2009.

Mueller, C., Brüggemann, N., Pritsch, K., Stoelken, G., Gayler, S., Winkler, J., and Kögel-Knabner, I.: Initial differentiation of vertical soil organic matter distribution and composition under juvenile beech (Fagus sylvatica L.) trees, Plant Soil, 323, 111-123, doi:10.1007/s11104-009-9932-1, 2009.

Mueller, K.: Oberflächenstrukturen und Eigenschaften von Permafrostböden im nordsibirischen Lena-Delta, Z. Pflanz. Bodenkunde, 160, 497-503, doi:10.1002/jpln.19971600410, 1997 (in German).

Naafs, D. F. W., van Bergen, P. F., Boogert, S. J., and de Leeuw, J. W.: Solvent-extractable lipids in an acid andic forest soil; variations with depth and season, Soil Biol. Biochem., 36, 297-308, doi:10.1016/j.soilbio.2003.10.005, 2004.

Nelson, F. E., Shiklomanov, N. I., Hinkel, K. M., and Brown, J.: Decadal Results from the Circumpolar Active Layer Monitoring (CALM) Program, NICOP: Ninth internationcal conference on permafrost, 29 June-3 July 2008, University of Alaska Fairbanks, 1273-1280, 2008.

Pfeiffer, E.-M., Wagner, D., Kobabe, S., Kufzbach, L., A. Kurchatova, Stoof, G., and Wille, C.: Modern Processes in Permafrost Affected Soils, Reports on Polar and Marine Research, 426, 2141, 2002.

Poirier, N., Sohi, S. P., Gaunt, J. L., Mahieu, N., Randall, E. W., Powlson, D. S., and Evershed, R. P.: The chemical composition of measurable soil organic matter pools, Org. Geochem., 36, 1174-1189, 2005.

Quideau, S. A., Anderson, M. A., Graham, R. C., Chadwick, O. A., and Trumbore, S. E.: Soil organic matter processes: characterization by 13C NMR and 14C measurements, Forest Ecol. Manag., 138, 19-27, 2000.

Rethemeyer, J., Kramer, C., Gleixner, G., John, B., Yamashita, T., Flessa, H., Andersen, N., Nadeau, M.-J., and Grootes, P. M.: Transformation of organic matter in agricultural soils: radiocarbon concentration versus soil depth, Geoderma, 128, 94-105, 2005.

Rethemeyer, J., Fülöp, R. H., Höfle, S., Wacker, L., Heinze, S., Hajdas, I., Patt, U., König, S., Stapper, B., and Dewald, A.: Status report on sample preparation facilities for $14 \mathrm{C}$ analysis at the new CologneAMS center, Nuclear Instruments and Methods in Physics Research Section B: Beam Interactions with Materials and Atoms, 294, 168-172, doi:10.1016/j.nimb.2012.02.012, 2013.

Romanovskii, N. N. and Hubberten, H.-W.: Results of permafrost modelling of the lowlands and shelf of the Laptev Sea Region, Russia, Permafrost Periglac., 12, 191-202, doi:10.1002/ppp.387, 2001

Rumpel, C. and Kögel-Knabner, I.: Deep soil organic matter - a key but poorly understood component of terrestrial C cycle, Plant Soil, 338, 143-158, doi:10.1007/s11104-010-0391-5, 2011.
Rumpel, C., Eusterhues, K., and Kögel-Knabner, I.: Location and chemical composition of stabilized organic carbon in topsoil and subsoil horizons of two acid forest soils, Soil Biol. Biochem., 36, 177-190, 2004.

Sanaullah, M., Chabbi, A., Leifeld, J., Bardoux, G., Billou, D., and Rumpel, C.: Decomposition and stabilization of root litter in topand subsoil horizons: what is the difference?, Plant Soil, 338, 127-141, doi:10.1007/s11104-010-0554-4, 2011.

Schaefer, K., Zhang, T., Bruhwiler, L., and Barrett, A. P.: Amount and timing of permafrost carbon release in response to climate warming, Tellus B, 63, 165-180, doi:10.1111/j.16000889.2011.00527.x, 2011.

Schöning, I. and Kögel-Knabner, I.: Chemical composition of young and old carbon pools throughout Cambisol and Luvisol profiles under forests, Soil Biol. Biochem., 38, 2411-2424, 2006.

Schubert, C. J. and Stein, R.: Lipid Distribution in surface sediments from the eastern central Arctic Ocean, Mar. Geol., 138, 11-25, 1997.

Semiletov, I. P., Pipko, I. I., Shakhova, N. E., Dudarev, O. V., Pugach, S. P., Charkin, A. N., McRoy, C. P., Kosmach, D., and Gustafsson, Ö.: Carbon transport by the Lena River from its headwaters to the Arctic Ocean, with emphasis on fluvial input of terrestrial particulate organic carbon vs. carbon transport by coastal erosion, Biogeosciences, 8, 2407-2426, doi:10.5194/bg8-2407-2011, 2011.

Simpson, M. and Simpson, A.: The Chemical Ecology of Soil Organic Matter Molecular Constituents, J. Chem. Ecol., 38, 768784, doi:10.1007/s10886-012-0122-x, 2012.

Six, J., Conant, R. T., Paul, E. A., and Paustian, K. Stabilization mechanisms of soil organic matter: Implications for C-saturation of soils, Plant Soil, 241, 155-176, doi:10.1023/a:1016125726789, 2002.

Sollins, P., Homann, P., and Caldwell, B. A.: Stabilization and destabilization of soil organic matter: mechanisms and controls, Geoderma, 74, 65-105, 1996.

Sollins, P., Swanston, C., Kleber, M., Filley, T., Kramer, M., Crow, S., Caldwell, B. A., Lajtha, K., and Bowden, R.: Organic C and $\mathrm{N}$ stabilization in a forest soil: Evidence from sequential density fractionation, Soil Biol. Biochem., 38, 3313-3324, doi:10.1016/j.soilbio.2006.04.014, 2006.

Sollins, P., Kramer, M. G., Swanston, C., Lajtha, K., Filley, T., Aufdenkampe, A. K., Wagai, R., and Bowden, R. D.: Sequential density fractionation across soils of contrasting mineralogy: evidence for both microbial- and mineralcontrolled soil organic matter stabilization, Biogeochemistry, 96, 209-231, doi:10.1007/s10533-009-9359-z, 2009.

Trumbore, S.: Radiocarbon and Soil Carbon Dynamics, Annu. Rev. Earth Pl. Sc., 39, 47-66, doi:10.1146/annurev.earth.36.031207.124300, 2009.

van Dongen, B. E., Semiletov, I., Weijers, J. W. H., and Gustafsson, Ö.: Contrasting lipid biomarker composition of terrestrial organic matter exported from across the Eurasian Arctic by the five great Russian Arctic rivers, Global Biogeochem. Cy., 22, GB1011, doi:10.1029/2007gb002974, 2008.

von Lützow, M., Kögel-Knabner, I., Ekschmitt, K., Flessa, H., Guggenberger, G., Matzner, E., and Marschner, B.: SOM fractionation methods: Relevance to functional pools and to stabilization mechanisms, Soil Biol. Biochem., 39, 2183-2207, doi:10.1016/j.soilbio.2007.03.007, 2007. 
von Lützow, M., Kögel-Knabner, I., Ludwig, B., Matzner, E., Flessa, H., Ekschmitt, K., Guggenberger, G., Marschner, B., and Kalbitz, K.: Stabilization mechanisms of organic matter in four temperate soils: Development and application of a conceptual model, J. Plant Nutr. Soil Sc., 171, 111-124, doi:10.1002/jpln.200700047, 2008.

Vonk, J. E.: Molecular and isotopic characterization of terrestrial organic carbon released to (sub-)Arctic coastal waters, Ph.D. thesis, Department of Applied Environmental Science, Stockholm University, Stockholm, 51 pp., 2010.

Wagner, D., Gattinger, A., Embacher, A., Pfeiffer, E.-M., Schloter, M., and Lipski, A.: Methanogenic activity and biomass in Holocene permafrost deposits of the Lena Delta, Siberian Arctic and its implication for the global methane budget, Glob. Change Biol., 13, 1089-1099, doi:10.1111/j.1365-2486.2007.01331.x, 2007.

Wakeham, S. G., Canuel, E. A., Lerberg, E. J., Mason, P., Sampere, T. P., and Bianchi, T. S.: Partitioning of organic matter in continental margin sediments among density fractions, Mar. Chem., $115,211-225,2009$.
Waldrop, M. P., Wickland, K. P., White III, R., Berhe, A. A., Harden, J. W., and Romanovsky, V. E.: Molecular investigations into a globally important carbon pool: permafrost-protected carbon in Alaskan soils, Glob. Change Biol., 16, 2543-2554, doi:10.1111/j.1365-2486.2009.02141.x, 2010.

Xu, C., Guo, L., Ping, C.-L., and White, D. M.: Chemical and isotopic characterization of size-fractionated organic matter from cryoturbated tundra soils, northern Alaska, J. Geophys. Res., 114, G03002, doi:10.1029/2008jg000846, 2009.

Zimov, S. A., Davydov, S. P., Zimova, G. M., Davydova, A. I., Schuur, E. A. G., Dutta, K., and Chapin III, F. S.: Permafrost carbon: Stock and decomposability of a globally significant carbon pool, Geophys. Res. Lett., 33, L20502, doi:10.1029/2006GL027484, 2006.

Zubrzycki, S., Kutzbach, L., Grosse, G., Desyatkin, A., and Pfeiffer, E.-M.: Organic carbon and total nitrogen stocks in soils of the Lena River Delta, Biogeosciences Discuss., 9, 17263-17311, doi:10.5194/bgd-9-17263-2012, 2012. 